Canadian Journal of Family and Youth, 11(1), 2019, pp. 202-227

ISSN 1718-9748@ University of Alberta

http://ejournals,library,ualberta.ca/index/php/cjfy

\title{
Are Millennials really Picking Pets over People? Taking a Closer look at Dog Ownership in Emerging Adulthood
}

\author{
Taryn M. Graham, Katrina J. Milaney, Cindy L. Adams, Melanie J. Rock
}

\begin{abstract}
This paper draws on the work of Bourdieu to understand how experiences with dog ownership become embodied and how these experiences influence young people's development as they leave home and learn to mobilize any capital to which they have access. Our results show that dogs can provide everyday routine during a stage in life when young people often experience instability. Additionally, dogs may help to shift the focus beyond self, thereby influencing how, and with whom, millennials spend their time. Nonetheless, balancing dog ownership with education, work, dating, social life, and other obligations could become challenging. Overall, this paper highlights that young people's access to resources, including housing, may influence their capacities to experience all the benefits that pet ownership purports to offer. Dog ownership has numerous implications for healthy development among millennials, yet greater support may be needed to facilitate smoother transitions.
\end{abstract}

Dr. Taryn M Graham recently completed her PhD in Community Health Sciences at the University of Calgary. Her research looks into the challenges and opportunities that cities face when it comes to sharing spaces with dogs. Topics she has studied thus far include: community development in dog parks; physical activity through dog walking; policies on pets in housing and neighbourhood contexts; pet-keeping practices among millennials; and the social justice implications of how society relates to and thinks of animals. For the past decade, Taryn has been actively involved with many animal rescue organizations. She also has experience training dogs.

Dr. Katrina J Milaney is an Assistant Professor in Community Rehabilitation and Disability Studies at the University of Calgary. She has an interdisciplinary academic background and has several years in community-based research. Katrina is a qualitative researcher who uses critical theory frameworks to study social determinants of health.

Dr. Cindy L Adams is a Professor in Veterinary Clinical and Diagnostic Sciences at the University of Calgary. She is an epidemiologist (PhD) and social worker (MSW) whose work focuses on improving communication practices in veterinary medicine and education. Some of her research interests include: communication skills teaching; learning and assessment; human-animal interactions; animal, child, social welfare; population health; and relational coordination.

Dr. Melanie J Rock is an Associate Professor in Community Health Sciences at the University of Calgary. She is an anthropologist (PhD) and social worker (MSW) whose research focuses on the societal and cultural dimensions of health, with an emphasis on the importance of animals for mental, physical, and social wellbeing. 


\section{Introduction}

Throughout Western industrialized societies, the process of becoming an adult has tended to involve transitioning from education to employment, from living with parents to leaving home, and from being single to forming a family (Arnett, 2000). Yet, these role transitions have become delayed, to such a degree that dog ownership may be more attainable for young people today than job stability, homeownership, or childrearing. As a recent Washington Post headline proclaimed, 'Millennials are picking pets over people' (Bhattarai, 2016), implying that members of this generation are turning to pets to satisfy their caretaking needs. At the same time, much of the media attention on millennials presumes that young people today are lazy, entitled, or selfish, given the time it now takes for them to settle down. In 2013, for instance, Time Magazine issued a cover story, titled: "Millennials: The Me Me Me Generation" (Stein, 2013). In this paper, we challenge such simplistic conclusions about millennials and their pets, by exploring the roles of dogs in the lives of emerging adults.

The popularity of pets among millennials cannot be adequately understood without first considering the challenges this generation faces. Becoming an adult today generally involves some form of postsecondary education. However, rising costs of living combined with higher tuition fees have diminished young people's capacities to leave home and to sever financial ties with their families while pursuing postsecondary education (Clarke, 2007). Among those who do leave home, many go on to live in the rental market for longer than previous generations, and some may never be able to afford homeownership, giving rise to the moniker "generation rent" (McKee, 2012). Not only is it harder for millennials to pay for education or to buy a home than it 
Are Millennials really Picking Pets over People?

was for their parents at the same age, but jobs have become less secure and careers are more fluid than in the recent past (Lewchuk, Clarke, \& De Wolff, 2008). As a consequence of these changes, marriage and parenthood tend to occur much later, if at all (Arnett, 2007).

Delayed transitions are not new. In fact, two decades ago, psychologist Jeffrey Jensen Arnett (1998) began to study what it means to become an adult. He noticed that transitions to adulthood had changed since the 1950s, when psychologist Erik H. Erikson first introduced his theory of psychosocial development, postulating that young people tend to move directly from “adolescence," lasting from puberty to age 18, into "young adulthood," lasting from age 19 to around age 40 when middle adulthood began. However, when asking young people aged between 18 and 25 whether they had reached adulthood, Arnett (2000) noticed that they tended to respond with, "in some respects yes, in some respects no" (p. 471). They also reported pondering their identity, a theme that interested Arnett, since according to Erikson's (1950) theory of development, most would have settled that question by the age of 18. As a result, in 2000, Arnett proposed a new developmental stage between adolescence and young adulthood, which he called "emerging adulthood."

Emerging adulthood is characterized by five distinctive features: It is an age of identity exploration; instability; self-focus; feeling in-between, and trying out possibilities (Arnett, 2000). The age range of emerging adulthood is generally from the late teens to the mid- to late twenties (Arnett, 2014); however, the upper age limit is flexible and may now apply to some in their thirties, since growing proportions of young people do not establish stable, autonomous residence until then (Mitchell, 2006). Emerging adulthood is marked by frequent change, so a 
Graham, Milaney, Adams and Rock

great deal of diversity exists during this developmental stage, particularly when it comes to young people's living arrangements. Most emerging adults live with one or both parents, whereas others may leave home, only to return at some point, or even at many points (Furlong, Cartmel, Biggart, Sweeting, \& West, 2003; Molgat, 2007). Overall, residential changes tend to peak during emerging adulthood, often taking place at the start or end of periods of exploration in love, work, or education (Arnett, 2000).

Crucially, Arnett acknowledges that the capacity to devote a period of life to "explorations of various kinds is not equally available to all young people" (p. 477), thus different millennials may face different trajectories, depending on their upbringing and access to resources. For instance, not all parents can afford to accommodate their millennial children and not all parent-child relationships are conducive to extended co-residence in a family home. Nonetheless, previous research has found that supportive parents and peers can act as stabilizers in young people's adjustments to independent living (Heath \& Calvert, 2013; Mann-Feder, Eades, Sobel, \& De Stafano, 2014). As Côté \& Bynner (2008) caution, young people more than ever require access to resources to "develop a stable sense of self rooted in the adult roles they elect to adopt" (p. 262).

Few studies have examined the roles of pets in the lives of emerging adults; however, pets have been recognized for their protective effects on people's health since the 1980s (McNicholas et al., 2005). This lack of attention to pet ownership during emerging adulthood is surprising given that Hodgson and Darling (2011) explored pets in the family life cycle, noting that after leaving home, young people often acquire a pet with which they establish patterns of 
Are Millennials really Picking Pets over People?

intimacy as an aspect of transitioning into independent living. Moreover, based on survey data with 241 college students in the US, young people often believe that pet keeping reduces loneliness and that pets can help them get through hard times (Staats, Wallace, \& Anderson, 2008), which may help facilitate smoother transitions.

In the study that follows, we will explore how millennials describe the impacts of dog ownership on their identities, relationships, and environments. There are varying opinions about the actual age range of millennials. Earlier sources define millennials as born between 1980 and 2000 (Taylor \& Keeter, 2010), whereas most recent research defines them as born between 1981 and 1996 (Dimock, 2018). Between them, these two sources indicate that, in 2018, millennials are aged somewhere between 18 and 38, meaning that many of them fall within the age span of emerging adulthood. In this paper, we focus on the experiences of 28 dog owners, aged 21 to 31 , all of whom are housed in the rental market. We elected to focus on dog ownership because dogs are the pets most likely to venture with their owners into the broader community (Wood et al., 2005), thus having the potential to facilitate interactions with other people. At the same time, landlords often ban dogs from rental housing (Carlisle- Frank, Frank, \& Nielsen, 2005, Power, 2017), which impacts where and how people with pets may live. Bans and surcharges on pets may impact emerging adults disproportionally, since they are more likely to be tenants, if they can find rental housing at all.

\section{Methodology}

\section{Conceptual framework}

To show how young people's trajectories take place through an interplay of choice 
Graham, Milaney, Adams and Rock

(agency) and unequal chances (structure), in this paper, we will draw on key concepts introduced by Bourdieu (1986), namely habitus, capitals, and fields. Through habitus, "one comes to determine what is possible ... for one's life and develops aspirations ... accordingly" (Dumais, 2002, p. 46). Habitus is rooted in the different forms of resources to which a person has access to, namely “economic capital” (i.e., property and wealth); "cultural capital” (i.e., education and skills); and "social capital" (i.e., networks and relations). Thus, to get by and get ahead - or as Bourdieu puts it, to navigate a certain "field" - one must mobilize any capital to which one has access (see Figure 10).

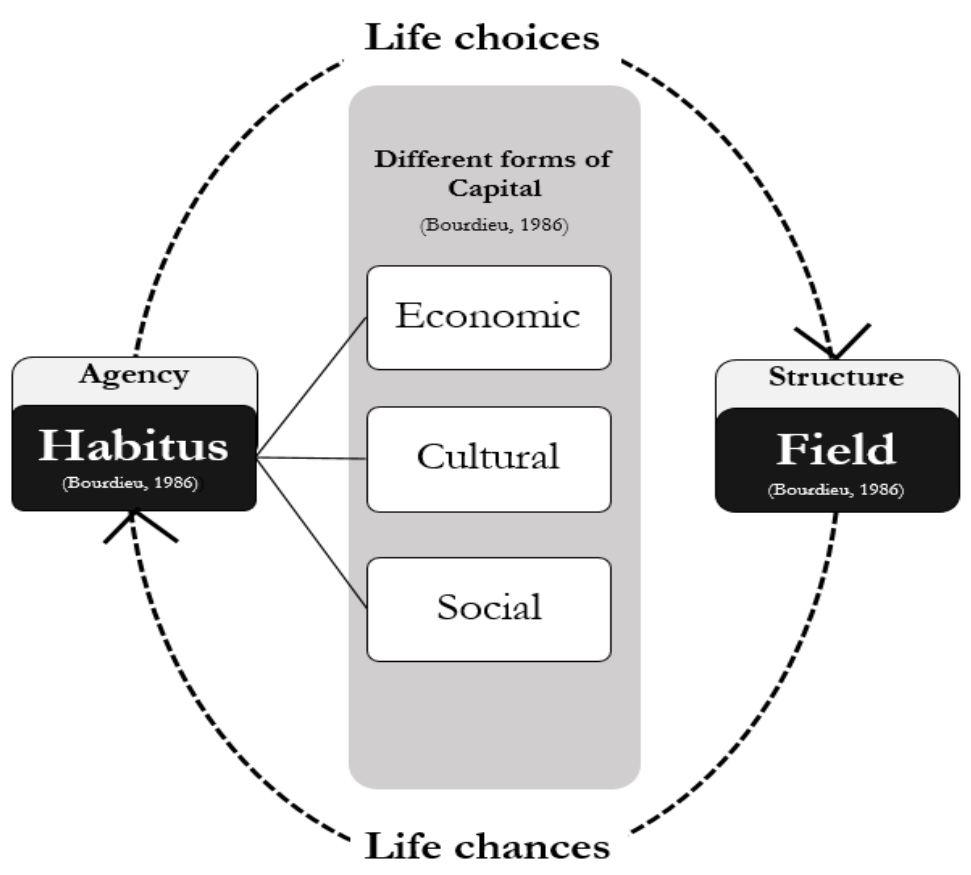

Figure 1. How trajectories take place through an interplay of agency and structure 
Are Millennials really Picking Pets over People?

For the purposes of this paper, housing is a key field. Housing influences physical, mental, and social wellbeing (Dunn, 2000). Thus, understanding young people's living circumstances, and how they struggle to accumulate, exchange, and mobilize different forms of resources once they are housed in the rental market, offers an important opportunity to promote healthy development and reduce inequities.

By way of illustration, a young person who is wealthy, or whose family is wealthy, may avoid rental housing altogether by moving directly into homeownership upon leaving home. Should this young person wish to rent, they are likely to find a property in a neighborhood of their preference. Young people with financial resources may also carry the knowledge and skills needed to gain certain advantages in negotiating rental housing, such as knowing how to complete the requisite paperwork, and how to dress and act appropriately when viewing a unit. Finally, assuming this young person is socially connected, they may gain insights into housing options that have not been advertised to others. By contrast, a young person with access to fewer resources may face greater challenges finding rental housing, which would be further complicated if they required a place that accept pets.

\section{Research setting}

The Canadian city of Calgary offers a useful setting to explore how millennials describe the impacts of dog ownership on their identities, relationships, and environments for two reasons. Firstly, Calgary has one of the youngest populations across Canada's major cities, with a median age of 36 . Just $29 \%$ of young people live with their parents in Calgary, as compared to the national average of 35\% (Statistics Canada, 2016). Secondly, Calgary has earned an international 
Graham, Milaney, Adams and Rock

reputation for its pet-friendly policies and services (Rock et al., 2014). Nonetheless, landlordtenant relations are handled at the provincial level, and the current legislation permits bans, restrictions, and surcharges on pet ownership in rental housing (Centre for Public Legal

Education in Alberta, 2013). Furthermore, the Canadian government has reduced its investments in rental housing since the 1970 s and has introduced a series of policies that favour homeownership, including apartments and townhomes that are set up as condominiums (City of Calgary, 2007). Hence, our study provides an opportunity to understand how millennial tenants navigate local environments that bear the imprint of policies at multiple levels.

\section{Data collection}

This qualitative study centres on semi-structured interviews. Participants were recruited through announcements shared on social media (i.e., Facebook and Twitter) and through posters displayed on bulletin boards at local university and college campuses, as well as within and near off-leash parks. To be interviewed, prospective participants had to self-identify as dog owners; be between 18 and 34 years of age; live in Calgary; and have sought rental housing for themselves and their dogs in the past five years.

The first author conducted the interviews personally, in neighborhood coffee shops or in library meeting rooms. In addition, the first author took fieldnotes before and after each interview and kept a reflexive journal throughout the research process. The interviews lasted approximately one hour each, and an honorarium was offered for participation (i.e., CAD\$25 grocery gift card). Each participant provided written consent that allowed them to be interviewed and audiotaped, following an informed consent process that outlined procedures for assuring 
Are Millennials really Picking Pets over People?

anonymity and the freedom to withdraw from the study. The first author transcribed each interview verbatim, employing memo-writing throughout. It is important to note that the first author met all inclusion criteria to be interviewed. The University of Calgary Research Ethics Board approved the study.

\section{Data analysis}

To analyze the data, the first author conducted qualitative thematic analysis (Braun \& Clarke, 2006). The analytic process involved imposing theoretically relevant categories that had been identified both through memo-writing and reviewing literature. These categories included identifying the benefits and challenges of dog ownership and weighing these against other demands and constraints that young people face today. Keeping in line with this approach, the transcripts were read and discussed a number of times. First, the transcripts were read to gain a broad understanding of both the benefits and challenges of dog ownership. Next, these benefits and challenges were considered in relation the five key features of emerging adulthood (i.e., identity exploration; instability; self-focus; feeling in-between, and trying out possibilities). Finally, the transcripts were read once more in relation to Bourdieu's (1986) insights regarding the different kinds of capitals to which participants had access. At this point, all authors gathered to discuss the proposed themes and subthemes, which were then refined.

In the end, the data were organized according to key developmental tasks in emerging adulthood, namely identity, intimacy, and autonomy. These a priori themes reflect key events in the literature. For instance, according to Erikson's (1950) psychosocial development theory, in each stage of life, there is a crisis to resolve, which can have a positive or negative outcome. 
Graham, Milaney, Adams and Rock

Adolescence is marked by "identity versus role confusion" and young adulthood by "intimacy versus isolation". Meanwhile, Arnett (2003) highlights autonomy as an important criterion for becoming an adult.

\section{Findings}

In what follows, we will begin by describing the participants of our study. Next, we will show how dog ownership can assist with key developmental tasks in emerging adulthood. For simplicity's sake, we will abbreviate participants to $\mathrm{P}$ when presenting their perspectives.

\section{Participants}

A total of 28 millennials ( 20 women; 8 men), aged 21 to 31, were interviewed for this study (see Table 3). All were living in rental housing at the time of the interviews. Sixteen kept one dog, five kept two dogs, and the remaining kept a combination of dogs and cats. Twenty-one were born in Canada, while the remaining participants emigrated from Brazil, Ireland, France, Mexico, Poland, Russia, and Vietnam. Eight were single, six were in a relationship, four were living common-law, four were engaged to be married, two were married, two were divorced, and two identified their relationship status as "it's complicated." Ten had completed high school, while four practiced a trade, twelve held bachelor's degrees, and two were pursuing graduate degrees. Based on our analysis, we do not cite two of the participants in our findings, namely P12 and P14, because they had human children in the home and exploring the pet keeping practices of millennial parents was beyond the scope of this study. 
Are Millennials really Picking Pets over People?

Table 1. Overview of participants recruited for interviews, all of whom are housed in rental housing

\begin{tabular}{|c|c|c|c|c|c|c|c|c|c|}
\hline Participant & Gender & Age & $\begin{array}{l}\text { Relationship } \\
\text { Status }\end{array}$ & Ethnicity & Occupation & $\begin{array}{c}\text { Highest } \\
\text { level of } \\
\text { education } \\
\text { completed }\end{array}$ & Pet(s) & $\begin{array}{l}\text { Relationship } \\
\text { to dog(s) }\end{array}$ & $\begin{array}{l}\text { Human household composition at } \\
\text { the time of interview }\end{array}$ \\
\hline 1 & M & 23 & $\begin{array}{c}\text { It's } \\
\text { complicated }\end{array}$ & Canadian & Fire paramedic & High school & $1 \operatorname{dog}$ & Child & Lived alone \\
\hline 2 & $\mathrm{~F}$ & 30 & Single & Vietnamese & $\begin{array}{l}\text { Receptionist at a } \\
\text { dental clinic }\end{array}$ & High school & 2 dogs & Children & Lived alone \\
\hline 3 & $\mathrm{~F}$ & 22 & $\begin{array}{c}\text { In a } \\
\text { relationship }\end{array}$ & Canadian & $\begin{array}{l}\text { Hired research } \\
\text { assistant }\end{array}$ & $\begin{array}{c}\text { Bachelor's } \\
\text { degree }\end{array}$ & $1 \operatorname{dog}$ & Child & Lived with sibling \\
\hline 4 & $\mathrm{~F}$ & 24 & Single & Canadian & $\begin{array}{c}\text { Social work } \\
\text { student }\end{array}$ & $\begin{array}{c}\text { Bachelor's } \\
\text { degree }\end{array}$ & $1 \mathrm{dog}$ & Child & Lived alone \\
\hline 5 & M & 28 & Single & Canadian & $\begin{array}{c}\text { Director of } \\
\text { enterprise } \\
\text { solutions at a job } \\
\text { search website } \\
\end{array}$ & $\begin{array}{l}\text { Bachelor's } \\
\text { degree }\end{array}$ & $1 \operatorname{dog}$ & Friend & Lived with roommates \\
\hline 6 & $\mathrm{~F}$ & 24 & Single & Canadian & $\begin{array}{l}\text { Health care aid and } \\
\text { nursing student }\end{array}$ & Trade & $1 \operatorname{dog}$ & $\begin{array}{c}\text { "Most } \\
\text { demanding } \\
\text { boyfriend" }\end{array}$ & Lived with roommate \\
\hline 7 & M & 25 & Engaged & Canadian & $\begin{array}{l}\text { Biological sciences } \\
\text { student and animal } \\
\text { health technician }\end{array}$ & $\begin{array}{l}\text { Bachelor's } \\
\text { degree }\end{array}$ & $\begin{array}{c}2 \\
\text { dogs, } \\
1 \text { cat }\end{array}$ & Family & Lived with partner \\
\hline 8 & $\mathrm{~F}$ & 28 & Single & Russian & $\begin{array}{l}\text { Quality assurance } \\
\text { technician }\end{array}$ & $\begin{array}{l}\text { Bachelor's } \\
\text { degree }\end{array}$ & $1 \operatorname{dog}$ & Family & Lived alone \\
\hline 9 & $\mathrm{~F}$ & 25 & Common-law & Canadian & $\begin{array}{c}\text { Sales and } \\
\text { distribution for } \\
\text { family business }\end{array}$ & $\begin{array}{l}\text { High } \\
\text { School }\end{array}$ & 2 dogs & $\begin{array}{l}\text { Sibling and } \\
\text { "Grumpy Old } \\
\text { Uncle" }\end{array}$ & Lived with partner \\
\hline 10 & $\mathrm{~F}$ & 31 & Common-law & Canadian & $\begin{array}{c}\text { Communications } \\
\text { coordinator for } \\
\text { community-based } \\
\text { organization }\end{array}$ & Trade & 2 dogs & Children & Lived with partner \\
\hline 11 & $\mathrm{~F}$ & 21 & Common-law & Canadian & $\begin{array}{c}\text { Dental assisting } \\
\text { student }\end{array}$ & $\begin{array}{l}\text { High } \\
\text { School }\end{array}$ & $1 \operatorname{dog}$ & Child & Lived with partner \\
\hline 12 & $\mathrm{~F}$ & 29 & Divorced & Canadian & $\begin{array}{c}\text { Archeology } \\
\text { student }\end{array}$ & $\begin{array}{l}\text { Graduate } \\
\text { degree }\end{array}$ & $1 \operatorname{dog}$ & Family & Lived with child \\
\hline 13 & M & 25 & Engaged & Canadian & $\begin{array}{l}\text { English Language } \\
\text { and Literature } \\
\text { student and } \\
\text { employee at steel } \\
\text { shop }\end{array}$ & Trade & $1 \operatorname{dog}$ & Child & Lived with partner \\
\hline 14 & $\mathrm{~F}$ & 26 & Married & Brazilian & $\begin{array}{c}\text { Open studies } \\
\text { student and Tim } \\
\text { Hortons employee }\end{array}$ & $\begin{array}{l}\text { Bachelor's } \\
\text { degree }\end{array}$ & $1 \operatorname{dog}$ & Child & Lived with partner and child \\
\hline 15 & $\mathrm{~F}$ & 28 & Engaged & France & Unemployed & $\begin{array}{l}\text { High } \\
\text { School }\end{array}$ & 2 dogs & Children & Lived with partner \\
\hline 16 & M & 25 & $\begin{array}{l}\text { In a } \\
\text { relationship }\end{array}$ & Canadian & $\begin{array}{c}\text { Information } \\
\text { Technology } \\
\text { representative }\end{array}$ & $\begin{array}{l}\text { Bachelor's } \\
\text { degree }\end{array}$ & $1 \operatorname{dog}$ & Family & Lived with partner \\
\hline 17 & $\mathrm{~F}$ & 28 & Married & Canadian & Dog groomer & $\begin{array}{l}\text { High } \\
\text { School }\end{array}$ & $\begin{array}{c}2 \\
\text { dogs, } \\
1 \text { cat }\end{array}$ & Children & Lived with partner \\
\hline 18 & $\mathrm{~F}$ & 30 & Single & Canadian & $\begin{array}{l}\text { Sales associate at a } \\
\text { pet store }\end{array}$ & $\begin{array}{l}\text { Bachelor's } \\
\text { degree }\end{array}$ & $\begin{array}{c}2 \\
\text { dogs; } \\
1 \text { cat }\end{array}$ & Children & Lived with roommates \\
\hline 19 & M & 29 & $\begin{array}{l}\text { In a } \\
\text { relationship }\end{array}$ & Irish & $\begin{array}{c}\text { Athletic therapy } \\
\text { student and bar } \\
\text { manager }\end{array}$ & $\begin{array}{l}\text { High } \\
\text { School }\end{array}$ & 2 dogs & Family & Lived with roommates \\
\hline 20 & $\mathrm{~F}$ & 27 & Common-law & Canadian & First aid teacher & Trade & $2 \operatorname{dogs}$ & Family & Lived with partner \\
\hline 21 & $\mathrm{~F}$ & 24 & Single & Canadian & Legal assistant & $\begin{array}{c}\text { Bachelor's } \\
\text { degree }\end{array}$ & $1 \operatorname{dog}$ & Child & Lived alone \\
\hline 22 & $\mathrm{~F}$ & 22 & $\begin{array}{c}\text { It's } \\
\text { complicated }\end{array}$ & Mexican & $\begin{array}{l}\text { Cultural studies } \\
\text { student and dry- } \\
\text { cleaning worker }\end{array}$ & $\begin{array}{l}\text { High } \\
\text { School }\end{array}$ & $1 \operatorname{dog}$ & Family & Lived with parent and siblings \\
\hline 23 & M & 29 & Common-law & Polish & $\begin{array}{c}\text { Information } \\
\text { Technology } \\
\text { support worker }\end{array}$ & $\begin{array}{l}\text { Bachelor's } \\
\text { degree }\end{array}$ & $\begin{array}{l}1 \mathrm{dog} \\
1 \mathrm{cat}\end{array}$ & Friend & Lived with partner \\
\hline 24 & $\mathrm{~F}$ & 21 & $\begin{array}{c}\text { In a } \\
\text { relationship }\end{array}$ & Canadian & $\begin{array}{l}\text { Veterinary } \\
\text { assistant }\end{array}$ & $\begin{array}{l}\text { High } \\
\text { School }\end{array}$ & $1 \operatorname{dog}$ & Family & Lived alone \\
\hline
\end{tabular}


Graham, Milaney, Adams and Rock

\begin{tabular}{|c|c|c|c|c|c|c|c|c|c|}
\hline 25 & $\mathrm{~F}$ & 21 & Single & Canadian & $\begin{array}{c}\text { Doggie daycare } \\
\text { store manager; } \\
\text { dental assistant at } \\
\text { denture clinic; } \\
\text { dance teacher; and } \\
\text { Child studies } \\
\text { student } \\
\end{array}$ & $\begin{array}{l}\text { High } \\
\text { School }\end{array}$ & $1 \mathrm{dog}$ & Child & Lived with roommate \\
\hline 26 & $\mathrm{~F}$ & 26 & $\begin{array}{l}\text { In a } \\
\text { relationship }\end{array}$ & Canadian & $\begin{array}{l}\text { Customer support } \\
\text { representative for } \\
\text { internet provider }\end{array}$ & $\begin{array}{c}\text { Bachelor's } \\
\text { degree }\end{array}$ & $1 \mathrm{dog}$ & Child & Lived alone \\
\hline 27 & M & 29 & Engaged & Canadian & $\begin{array}{l}\text { Hired research } \\
\text { assistant; applying } \\
\text { for jobs }\end{array}$ & $\begin{array}{c}\text { Graduate } \\
\text { degree }\end{array}$ & $1 \operatorname{dog}$ & Sibling & Lived with partner and roommates \\
\hline 28 & $\mathrm{~F}$ & 28 & $\stackrel{\text { In a }}{\text { relationship }}$ & Canadian & $\begin{array}{l}\text { Biological sciences } \\
\text { student and } \\
\text { waitress }\end{array}$ & $\begin{array}{c}\text { Bachelor's } \\
\text { degree }\end{array}$ & $\begin{array}{l}1 \text { dog; } \\
2 \text { cats }\end{array}$ & Child & Lived with roommates \\
\hline
\end{tabular}

\section{Identity}

Dogs helped facilitate a better understanding of self. As P7 put it, "Getting to know a dog and its quirks are one of the best ways to learn more about who you are as a person." In fact, depending on their upbringing, some participants already saw dog ownership as part of their identities. For instance, P9 grew up on a ranch, so her family "always had some sort of animal around." In her words,

It was weird not having a dog the first few years I moved out here. I couldn't find anywhere to rent that would allow an animal and...being as young as I was, I was just trying to work and save some money. I only got a dog when I could find a place where I could support one. I think that was the hardest thing to adjust to. Not taking care of something. [Having a dog] makes you accountable. And it makes you think about things other than yourself.

Similarly, P5 shared that dog ownership "helps you grow up. You have that sense of responsibility ... realizing you don't come first." This sense of responsibility towards dogs influenced how emerging adults structured their time, which provided opportunities for making healthy choices. 
Are Millennials really Picking Pets over People?

\section{"Keeps you on track"}

Emerging adulthood is characterized as an age of instability, yet as P8 explained: "My dog provides structure to my life. My days center around making sure she is okay." As P22 put it, “you can't just do whatever you want ... having a dog to care for is important. It keeps you on track ... I've struggled with depression for most of my teenage years onwards. I can definitely say that having a dog has improved my mental health." Similarly, when P2 struggled with depression, she "did not want her dogs to feel sad because [she] was sad." As she explained, "Dogs have that intuition ... So, I feel like the happier that I am, the happier they are. The more that I go out and take them on dog walks and other stuff, the more I'm okay because I can go out there and be with them." Another example of how dogs kept emerging adults on track was by providing reason to circumvent negative influences from peers. As P19 shared: "My dogs give me an excuse to get out of situations I don't want to be in. Like leaving parties early or whatever. I'll just say, 'Oh, I have to go see the dogs. They've been on their own for a while.'”

\section{“Doesn't allow much room for impulsivity"}

Emerging adulthood is often understood as a time in people's lives where anything still feels possible; however, participants indicated that this level of freedom was somewhat restricted by dog ownership. As P4 noted, caring for a dog “doesn't allow much room for impulsivity,” in that going out after work “just can't happen." P5 revealed how, he "can't drop things on a whim and just go somewhere," unlike his friends without pets who "have spent semesters abroad or have gone travelling for a couple of months before turning 30." He continued: “And it's, like, I 
Graham, Milaney, Adams and Rock

can't really. Well, not without a whole lot of planning to coordinate with my parents [who live in another province] or extra costs to pay for dog boarding." P25 similarly shared that "you can't just do an impromptu trip to wherever." As P6 put it: "Could caring for my dog be holding me back from other things? Absolutely. But it's a holding me back that I enjoy.”

\section{"Forces me to focus my attention elsewhere"}

Emerging adulthood is characterized as an age of self-focus; however, participants indicated that dogs forced focus beyond self. As P11 remarked: "My dog forces me to get out and do stuff. He forces me to focus my attention elsewhere than just school." P25 found direction in life by focusing on her dog's needs, stating:

My dog has changed my career path. He's made me more patient and more understanding. The behavioural issues he came with [when I adopted him] have made me realize that when it comes to a special need or whatever...these things take time and require appropriate expectations.

This participant decided to pursue a career in special education because of the life lessons her dog had taught her.

Another example of how dogs forced focus beyond self was when P6 left her family home, only to become addicted to gaming. She remembered thinking to herself: "Something needs to change. This can't be the rest of my life." She acquired a dog and reported feeling guilty, "because [the dog] would just stare at [her] when [she]'d try to play video games." In her words: "Just like that, I stopped obsessively playing video games and spent more time outside. I now run and hike with my dog, and I never imagined doing any of that before.” 
Are Millennials really Picking Pets over People?

\section{Intimacy}

Development of intimacy during emerging adulthood was both enhanced and undermined through dog ownership in different situations. For some couples in our study, dogs helped establish a family identity. As P15 shared: “They're our fur babies! We don't plan on doing that whole baby stuff, so our dogs are our babies ... We even got a king-size bed [so that our dogs could sleep with us]." For others, dogs drove relationships apart. For example, difficulties arose when young people entered a relationship with dogs of their own. As P9 shared: "My boyfriend's dog didn't get along with my dog when we first moved in together. It was almost a deal breaker."

\section{“Dog as a very big anchor"}

P1 and his partner broke up shortly after welcoming a dog into their relationship. As he recalled, "She saw the dog as a very big anchor. That it would stop us from being able to do so much." Another example of how emerging adults were anchored by their dogs was when they needed to move. As P6 shared:

My ex kept the dog while I searched for another pet-friendly place. That was the only reason we kept in touch. When I'd call, he'd say, '[The dog] misses you. He keeps looking for you.' We inadvertently got back together because of [the dog] and because of how hard it was to find another place that accepts pets. It was an unhealthy relationship, so it wasn't long before I moved out [with the dog].

Before getting a pet, P26 was "following work and cheap housing and living with friends ... I had that young lifestyle going on .... It's a lot easier to move myself around [rather] than myself and an animal, so I waited to make sure that I was set up and kind of okay to care for a dog." Throughout his life, P27 always wanted a dog but: "living situations mostly didn't allow for it. I planned on having one eventually... [but] not this early. I didn't think I had the time, money, 
Graham, Milaney, Adams and Rock

energy, and all that stuff, but then I met my girlfriend [who had a dog]." He continued, "I hate to compare dogs to babies but if a baby happened right now, it might not be the most ideal situation but I'm sure I'd make it work. And it's pretty much the same thing with [our dog]."

\section{“If you can't deal [with my dog], then you're not for me"}

Some emerging adults faced challenges in dating, either because of the routines they had established with their pets or because involvement with their pet was so intense that it limited other activities. As P2 stated: "Some guys didn't like the fact that my dogs sleep in my bed. And I used to struggle with that. But now I'm like, 'Whatever. If you can't deal [with my dog], then you're not for me.' Obviously, my dogs are more important.” As P6 put it: “[M]y dog is a huge part of my life. My dog can and will veto you." In fact, when P27 start seeing his now fiancée, he recalled that "the first test of my worth was how well [her dog] took to me." Similarly, P19 stated: “My dogs come first. If I really liked someone and they didn't like my dogs, that just wouldn't fly. That's why I let girls know about my dogs from the start.” He continued: “[T]he girlfriend I have now, our first date was walking the dogs. She's a dog person so I didn't have to explain anything to her."

\section{Autonomy}

Most of the emerging adults in our study needed to ask for help with pet care responsibilities, which was challenging, given that the move toward adulthood is a move toward autonomy. As P24 explained, emerging adults may not "want to burden people" with pet care. P28 similarly mentioned: "It's the responsibility that I sometimes put on other people for help that stresses me. Now I have roommates so [pet care] has been much easier, but it was a lot more 
Are Millennials really Picking Pets over People?

work when it was just me."

\section{"Couldn't do it alone"}

Emerging adults often turned to their parents for support. As P4 put it: "I'm really fortunate that I have my mom and my dad who are always willing to watch [my dog].” P25 kept both dogs after she and her fiancé broke up, but she could not find another rental that would accept them: "I never thought I'd be in a position of having to leave one of my dogs with somebody else. As unfortunate as it was, I know my dog is happy living with my parents."

Peers were also called upon to help with pet care responsibilities. P3 decided to move in with her sibling, for instance, stating: "I couldn't do it alone. Well, maybe I could, but it would be very difficult to look after a pet, especially when working full-time." When searching for rental housing, P19 chose to move in with peers specifically "because they're good company for the dogs. Even if the roommates aren't walking them, it's just someone in the house with them." Asking for help was especially difficult when dogs had behavioural issues. As P6 remarked: "I know my dog can be a hassle, so I just feel better when I pay somebody else to do it as opposed to asking friends."

Some parents would even help cover costly veterinary bills. As P27 shared,

Luckily, my fiancée's parents are very supportive, so for some stuff, especially if it's an unforeseen expense, they'll pitch in, which is awesome. But I'd definitely say that costs play a role because we're both working on grad stipends, which aren't an awful lot.

P11 received similar aid when her dog unexpectedly needed surgery: "We were so stressed saving up for it. But then, my boyfriend's parents said they would pay for it. That took a huge 
Graham, Milaney, Adams and Rock

weight off our shoulders."

\section{“If something were to happen"}

Being able to provide veterinary care was one of the most basic ways that pet ownership was related to autonomy development during emerging adulthood. For instance, P4 reported feeling comfortable going to her veterinarian "probably more so than the average person because [she has] pet insurance so any time something comes up, [she is] not afraid to take her [dog]." P5 similarly shared, 'I've got pet insurance, which is super .... I mean it's not cheap ... but just the peace of mind it gives has been great." P25 also reported feeling at ease: "I have pet insurance. So [bringing my dog to the vet] is not really an issue."

Not all emerging adults could afford pet insurance, however, nor could they necessarily rely on their social networks for assistance. P6 went to a rural vet to overcome cost-related challenges. When she told the veterinarian that she was a student, he further reduced her dog's already affordable exam fee. In her words: “[I]f something were to happen, it's like, 'what would I do?' I'd obviously find a way [to pay] but that part is a bit stressful for me right now." When P16 was a student, he decided to get his dog sterilized through Calgary's free spay-and-neuter program: "At the time, I had no income essentially, so I qualified on the low-income plan so [my dog] was spayed for free, which went amazing."

\section{Discussion}

Emerging adulthood is considered an age of self-focus; yet, dogs in our study helped to shift the focus beyond self, which encouraged healthy habits and inspired direction in life. For 
Are Millennials really Picking Pets over People?

instance, one participant in our study reported leaving parties early, using his dogs as an excuse to get out of situations he did not want to be in. Another participant said that getting a dog allowed her to overcome a gaming addiction, prompting her to engage in physical activity instead in the form of dog walking. The many changes that happen during emerging adulthood can, in some circumstances, lead to increased risky behaviours, as a means of dealing with greater instability (Arnett, 2006); yet, in our study, dogs appeared to provide stability. Previous research with homeless youth has found that risky behaviours may decrease as a consequence of dog ownership (Lem et al., 2013; Rew, 2000; Taylor, Williams, \& Gray, 2004) and our results suggest this may also occur for emerging adults in the general population.

Today, the criteria that emerging adults consider most important for becoming an adult are not marriage nor parenthood, but, rather, accepting responsibility for one's self; making independent decisions; and achieving financial independence from parents (Arnett, 2003). This paper demonstrates that dogs factor into all the above. Dogs required emerging adults in our study to accept responsibility not only for themselves, but also for another living being. In terms of independent decision-making, participants were regularly faced with having to choose their dogs over other alternatives, which influenced how, and with whom, they spent their time. Despite these benefits, most emerging adults in our study needed to ask for help with pet care responsibilities, which they considered challenging, given that this is a time in their lives where they hope to feel autonomous. As Arnett, Žukauskienè, and Sugimura (2014) highlight, "feeling in-between might elicit feelings of depression and anxiety in some emerging adults, especially those who believe they should feel more adult at their current age than they actually are" (p. 572). 
Graham, Milaney, Adams and Rock

Financial concerns did not stop emerging adults in our study from keeping pets; however, these concerns did preoccupy them. For instance, those with limited access to financial resources or fragile family circumstances reported ruminating over what might happen if their pet were to ever fall ill. In response to this, some would mobilize their cultural capital; for instance, disclosing their student status to negotiate on veterinary bills. By contrast, those who were capable of investing in pet insurance, or who could rely upon their social networks for assistance, appeared to be less anxious about potential emergencies.

Peer support is important when young people leave home, as is having a parental safety net (Mann-Feder et al., 2014), so a lack of social networks could exacerbate any challenges millennials may face when trying to care for their pets. Our results show that parents were often called upon to help with pet care responsibilities. In one case, parents agreed to permanently keep their daughter's dog, given that she had just experienced a break-up and could not find rental housing that would accept two large dogs. Not all emerging adults had access to parental support, however. Some had parents living in other provinces or even other countries, so asking for help with pet keeping was not realistic.

Relationships with peers or partners helped replace the support that some parents could not or would not provide. For instance, to secure affordable rental housing, emerging adults in our study would sometimes live with others. Roommates could help with feeding pets or with taking them out. At the very least, roommates provided additional company for dogs while their owners were away at work or in school.

Dogs helped establish a family identity for some couples in our study in ways that offered 
Are Millennials really Picking Pets over People?

additional support with pet care responsibilities. This finding is supported by previous research, which showed that pets can bring couples together to act out parental-type roles (Maharaj \& Haney, 2015). For others in our study, the demands of dog ownership were so intense that they restricted opportunities for intimacy. One participant said his partner at the time saw their dog as limiting life's possibilities, which terminated their relationship. Further, an inability to find a place that accepts pets could mean that emerging adults may stay in unhealthy relationships or living situations. Pets are often restricted from rental housing (Carlisle-Frank et al., 2005; Power, 2017), so finding another place could be time-consuming following a break-up, so much so that in one case, a dog was used as a pretext to reunite a couple, but only temporarily.

\section{Conclusion}

By grounding "generation rent" within the emerging adulthood literature, and by drawing on key concepts introduced by Bourdieu (1986), this paper addresses three significant gaps in knowledge. Firstly, this paper considers how dogs may fit within the five key features of emerging adulthood (i.e., identity exploration; instability; self-focus; feeling in-between; and trying out possibilities). Secondly, this paper highlights how access to resources, including housing, may influence young people's capacities to balance dog ownership with other responsibilities. Finally, this paper raises complex questions about who is responsible for the welfare of pets and whether the risks and costs associated with dog ownership in emerging adulthood should be absorbed at the individual (micro-)level, community (meso-)level, or structural (macro-)level. 
Graham, Milaney, Adams and Rock

Dog ownership has numerous implications for healthy development among millennials, particularly when it comes to mental health. At the same time, dog ownership demands resource mobilization. The lengthening transition to adulthood over the past several decades poses significant challenges for young people, their families, and society at large. Today, the process of leaving home not only happens much later, but also tends to be coupled with confusion and loneliness (Mann-Feder et al., 2014). Our results show that dog ownership may help strengthen the skills and capacities of young people on the path to adulthood. At the same time, greater supports may be needed. Few issues include a need to alleviate any guilt or anxiety millennials may face in trying to meet their pets' needs and to help their families who may already be overburdened.

\section{Future research and practice}

There is still much to learn about dog ownership in emerging adulthood. Given the evidence that perceptions towards pets may change once a human child is introduced into the family dynamic (Blouin, 2013; Shir-Vertesh, 2012), further exploration of the roles of dogs in the lives of millennial parents is warranted. Nonetheless, emerging adults in our study tended to regard their pets as children or family, so we encourage researchers to examine the impacts of dog ownership on perceptions of parenthood. Another area of future research could include speaking to the partners, peers, or parents of millennial dog owners, to ask them how they feel about helping with pet care responsibilities. Veterinarians should also be consulted about their experiences with dog ownership in emerging adulthood, given that millennials now represent a majority of pet owners (American Pet Products Association, 2017), some of whom may not be 
Are Millennials really Picking Pets over People?

able to independently afford veterinary care. Millennials may expect the care of their pets to take priority over monetary aspects, which, according to Coe, Adams, and Bonnett (2007), presents challenges for veterinarians who must convey the rationale for costs, while also being considerate of people's financial circumstances. A final area of research could include comparing millennials' aspirations with their circumstances. Recent market research suggests that millennials list dogs before marriage or children as their top reasons for desiring homeownership (Berman, 2017). Because of this, US banks have started to use pet ownership in their advertisements, as an angle to push millennials toward homeownership (London, 2018), even though most young people today cannot afford to leave the rental market (McKee, 2012).

Regarding implications for practice, some emerging adults in our study reported realizing that they will outlive their pets, noting how this pet loss would result in a loss of identity. Anticipatory grief is important to recognize, especially for those with access to fewer supports, as losing a pet carries significant risks for mental health. This paper also emphasizes the need to strengthen and evaluate subsidized programs that aid with pet care responsibilities (Baker, Kutz, Toews, Edwards, \& Rock, 2018), and to implement other initiatives that reflect the realities of pet ownership for those experiencing a longer and more complex transition into adulthood. These supports are particularly important for young people whose parents may be unable to extend help because of limited resources. Dog-sharing programs may also help mitigate some of the challenges millennials face in trying to meet their pets' needs, given that roommates proved to be helpful with providing additional assistance. Finally, there is a need to accept pets in rental housing. Housing is intimately tied to young people's identities, relationships, and environments in ways that have implications for their health and quality of life. 
Graham, Milaney, Adams and Rock

\section{References}

American Pet Products Association (2017). National Pet Owners Survey. Retrieved from http://www.americanpetproducts.org/pubs_survey.asp

Arnett, J. J. (2000). Emerging adulthood: A theory of development from the late teens through the twenties. American Psychologist, 55(5), 469.

(2007). Emerging adulthood: What is it, and what is it good for? Child Development Perspectives, 1(2), 68-73.

(2014). Emerging adulthood: The winding road from the late teens through the twenties, 2nd ed.. New York: Oxford University Press.

Arnett, J. J., Žukauskienè, R., \& Sugimura, K. (2014). The new life stage of emerging adulthood at ages 18-29 years: implications for mental health. The Lancet Psychiatry, 1(7), 569576.

Baker, T., Kutz, S., Toews, L., Edwards, N., \& Rock, M. (2018). Are we adequately evaluating subsidized veterinary services? A scoping review. Preventive Veterinary Medicine, 157, 59-69.

Berman, J. (2017, Aug 13). These millennials are buying houses because they want their pets to have more space. Retrieved from https://www.marketwatch.com/story/do-pets-have-thepotential-to-unleash-millennials-on-housing-market-2017-08-02

Bernard, P., Charafeddine, R., Frohlich, K. L., Daniel, M., Kestens, Y., \& Potvin, L. (2007). Health inequalities and place: a theoretical conception of neighbourhood. Social Science \& Medicine, 65(9), 1839-1852.

Bhattarai, A. (2016, September 13). Millennials are picking pets over people. Washington Post. Retrieved from https://www.washingtonpost.com/news/business/wp/2016/09/13/millennials-are-pickingpets-over-people/?utm_term=.b29c254fc880

Blouin, D. (2013). Are dogs children, companions, or just animals? Understanding variations in people's orientations toward animals. Anthrozoös, 26(2), 279-294.

Bourdieu, P. (1986). The forms of capital. In J. Richardson (Ed.), Handbook of theory and research for the sociology of education (pp. 241-258). New York, NY: Greenwood.

Braun, V. \& Clarke, V. (2006). Using thematic analysis in psychology. Qualitative Research in Psychology, 3(2), 77-101.

Carlisle-Frank, P., Frank, J. M., \& Nielsen, L. (2005). Companion animal renters and petfriendly housing in the US. Anthrozoös, 18(1), 59-77. 
Are Millennials really Picking Pets over People?

Clarke, W. (2007). Delayed transitions of young adults. Canadian Social Trends, 84, 13-21.

Coe, J. B., Adams, C. L., \& Bonnett, B. N. (2007). A focus group study of veterinarians' and pet owners' perceptions of the monetary aspects of veterinary care. Journal of the American Veterinary Medical Association, 231(10), 1510-1518.

Coté, J. E. \& Bynner, J. (2008). Changes in the transition to adulthood in the UK and Canada: The role of structure and agency in emerging adulthood. Journal of Youth Studies, 11(3), 251-267.

Dimock, M. (2018, March 1). Defining generations: Where Millennials end and post-Millennials begin. Pew Research Centre. Retrieved from http://www.pewresearch.org/facttank/2018/03/01/defining-generations-where-millennials-end-and-post-millennialsbegin/?utm_content=bufferf59b9\&utm_medium=social\&utm_source=twitter.com\&utm_ campaign $=$ buffer

Dumais, S. A. (2002). Cultural capital, gender, and school success: The role of habitus. Sociology of Education, 75(1), 44-68.

Dunn, J. R., Hayes, M. V., Hulchanski, J. D., Hwang, S. W., \& Potvin, L. (2006). Housing as a socio-economic determinant of health: Findings of a national needs, gaps and opportunities assessment. Canadian Journal of Public Health, S11-S15.

Erikson, E. H. (1950). Childhood and Society. New York, NY: Norton.

Furlong, A., Cartmel, F., Biggart, A., Sweeting, H., \& West, P. (2003) Youth transitions: Patterns of vulnerability and processes of social inclusion. Edinburgh, UK: Scottish Executive Social Research.

Heath, S. \& Calvert, E. (2013). Gifts, loans and intergenerational support for young adults. Sociology, 47(6), 1120-1135.

Hodgson, K. \& Darling, M. (2011). Pets in the family: Practical approaches. Journal of the American Animal Hospital Association, 47(5), 299-305.

Lem, M., Coe, J. B., Haley, D. B., \& Stone, E. (2013). Effects of companion animal ownership among Canadian street-involved youth: A qualitative analysis. Journal of Sociology \& Social Welfare, 40, 285.

Lewchuk, W., Clarke, M., \& De Wolff, A. (2008). Working without commitments: Precarious employment and health. Work, Employment and Society, 22(3), 387-406.

London, K. (2018, Feb). Dogs in need of yards - Banks use this angle to push home ownership. The Bark. Retrieved from https://thebark.com/content/dogs-need-yards 
Graham, Milaney, Adams and Rock

Mann-Feder, V., Eades, A., Sobel, E., \& De Stafano, J. (2014). Leaving home: A qualitative study. Canadian Journal of Family and Youth, 6(1), 1-28.

Maharaj, N. \& Haney, C. (2015). A qualitative investigation of the significance of companion dogs. Western Journal of Nursing Research, 37(9), 1175-1193.

McKee, K. (2012). Young people, homeownership and future welfare. Housing Studies, 27(6), 853-862.

McNicholas, J., Gilbey, A., Rennie, A., Ahmedzai, S., Dono, J. A., \& Ormerod, E. (2005). Pet ownership and human health: A brief review of evidence and issues. British Medical Journal, 331(7527), 1252-1254.

Mitchell, B. A. (2006). The boomerang age: Transitions to adulthood in families. New Jersey: Aldine-Transaction.

Molgat, M. (2007). Do transitions and social structure matter? How emerging adults define themselves as adults. Journal of Youth Studies, 10 (5), 495-516.

Power, E. R. (2017). Renting with pets: A pathway to housing insecurity? Housing Studies, 32(3), 336-360.

Rew, L. (2000). Friends and pets as companions: Strategies for coping with loneliness among homeless youth. Journal of Child and Adolescent Psychiatric Nursing, 13(3), 125-132.

Shir-Vertesh, D. (2012). 'Flexible personhood': Loving animals as family members in Israel. American Anthropologist, 114(3), 420-432.

Staats, S., Wallace, H., \& Anderson, T. (2008). Reasons for companion animal guardianship (pet ownership) from two populations. Society \& Animals, 16(3), 279-291.

Stein, J. (2013). Millennials: The me me me generation. Time Magazine, 20, 1-8.

Tannen, D. (2004). Talking the dog: Framing pets as interactional resources in family discourse. Research on Language and Social Interaction, 37(4), 399-420.

Taylor, P. \& Keeter, S. (2010). Millennials: Confident. Connected. Open to Change. Pew Research Center. Retrieved from http://www.pewsocialtrends.org/2010/02/24/millennials-confident-connected-open-tochange/

Taylor, H., Williams, P., \& Gray, D. (2004). Homelessness and dog ownership: An investigation into animal empathy, attachment, crime, drug use, health and public opinion. Anthrozoos, 17(4), 353-368.

Wood, L., Giles-Corti, B., \& Bulsara, M. (2005). The pet connection: Pets as a conduit for social capital? Social Science \& Medicine, 61(6), 1159-1173. 